\title{
Use of Crab Shell (Ucides cordatus) in Portland Cement Matrices
}

\author{
Roldão Pimentel de Araújo Júnior ${ }^{1,2}$, Adão Lincon Bezerra Montel ${ }^{2}$, José Expedito Cavalcante da Silva², \\ Sergio Donizeti Ascêncio ${ }^{2} \&$ José Maria Rodrigues da $\mathrm{Luz}^{3}$ \\ ${ }^{1}$ Doutorando em Biotecnologia e Biodiversidade do Programa de Pós-Graduação da Rede Bionorte, Federal \\ University of Tocantins, Palmas, TO, Brazil \\ ${ }^{2}$ Federal University of Tocantins, Palmas, TO, Brazil \\ ${ }^{3}$ Postgraduate Multicenter Program of Biochemistry and Molecular Biology, Instituto de Ciências Farmacêuticas, \\ Universidade Federal de Alagoas, Maceió, AL, Brazil \\ Correspondence: José Expedito Cavalcante da Silva, Federal University of Tocantins, Palmas, TO, Brazil. Tel: \\ 55-063-3232-8007. E-mail: jecs@mail.uft.edu.br
}

Received: September 18, 2019

Accepted: October 27, 2019

Online Published: December 15, 2019

doi:10.5539/jas.v12n1p200

URL: https://doi.org/10.5539/jas.v12n1p200

\begin{abstract}
The high consume of crustaceans in human food has generated a large quantities of residues, such as the crab shell of Ucides cordatus (caranguejo-uçá), in Brazil. These residues are disposed in the environment. The development of new materials using crab shells chitin for biotechnological applications in civil construction is of great interest to the scientific community. The residues addition in the cement can reduce electricity consumption, $\mathrm{CO}_{2}$ emissions and other environmental damage from this human activity. Thus, the aims of this study were the use of $U$. Cordatus residues for hydroxyapatite and chitosan production and the incorporation of these compounds in Portland cement matrix, as a viable alternative to improve the properties of the paste and mortar when fresh or hardened. The crab shells were obtained from a fishermen's cooperative after meat extraction. The cement for the production of pastes and mortars was CPII F-40 Portland with filer. The proportion of biomaterial in the cement matrix was of 1 to $5 \%(\mathrm{w} / \mathrm{w})$. The physical and chemical properties of this material were determined in the fresh and hardened states. Biopolimers of the crab shells promoted changes in consistency, reduced setting time of pastes and mortars and an increase in strength to the axial compressive. These changes may be due to the hydrophilic groups of this compound and the greatest water retention that causes increase the number of nucleation points of the cement and paste grains becomes denser and homogeneous. Thus, the addition of biopolimers in the cement matrix may function as a polyfunctional additive. Furthermore, this process contributes to the reduction of environmental damage caused by improper disposal of crab shells and may represent an economic enhancement of this by-product of the food industry.
\end{abstract}

Keywords: chitosan, hydroxyapatite, biopolymer, biomaterials, fresh mortar, residues

\section{Introduction}

The high consume of crustaceans has generated large amounts of residues, such as shell and paws, in several regions of Brazil. These residues are approximately $50 \%$ of the total mass of animal and are disposed of in soil or water bodies. These discharges have caused a great environmental impact (Benchimol et al., 2006). But, the development of technology with crustacean residues can increase the economic and social potential of the fishing industry.

In 2014, the Filé do Mangue microenterprise was installed in the Bragança city, Pará state, Brazil with permission of the Pará State Agricultural Defense Agency (Adepará) for extraction and marketing of crabs. This company is Brazil's first private agro-industrial of crab meat production and slaughters about 3,000 animals a day.

In studies of Santos et al. (2017a, 2017b) carried out in the community of Treme, Bragança city, Pará state, Brazil, the residues from the crab are the shells, viscera and residual meat. According to these authors, because there is no waste management they are disposed of on vacant land near lakes and rivers.

Crab shells have high concentrations of chitin. The Ucides cordatus (caranguejo-uçá) is the second largest crustacean of the mangrove and has been used in the human food. Many methods have been developed for 
recovery of chemical compounds (e.g., proteins, chitin, and carotenoids) from crustacean processing residues (Abreu et al., 2013). Thus, studies of new materials for biotechnological applications of these residues have been of great interest to the scientific community. One such application may be chitin production from crab shells that are natural and renewable residues. According to Raya et al. (2015), in crab shells contain $40 \%$ to $70 \%$ calcium carbonate $\left(\mathrm{CaCO}_{3}\right)$ which can be transformed into calcium hydroxyapatite $\left(\mathrm{Ca}_{10}\left(\mathrm{PO}_{4}\right)_{6}(\mathrm{OH})_{2}\right)$. This compound is a calcium phosphate ceramic and one of the active ingredients (biocompatible and non-toxic) used in tooth demineralization processes and bone tissue regeneration. Furthermore, the calcium phosphate and chitosan addition in Portland cement matrix may contribute to flexibilities and strength of materials.

Thus, the aims of this study were the use of $U$. Cordatus residues for hydroxyapatite and chitosan production and the incorporation of these compounds in Portland cement matrix, as a viable alternative to improve the properties of the paste and mortar when fresh or hardened.

\section{Materials and Methods}

$U$. cordatus shells were obtained from the Filé do Mangue microenterprise after meat extraction. These shells were crushed, washed with drinking water and exposed to sunlight for seven days. The shells were kept in an oven at $60{ }^{\circ} \mathrm{C}$ for 4 hours to remove water and then they were ground for 2 hours in a ball mill. This powder was

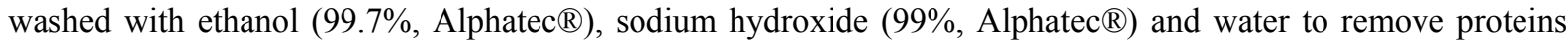
and lipids. The biopolymers (Hydroxyapatite and chitosan) were extracted by the addition of sulfuric acid ( $0.5 \%$, Alphatec $\left({ }^{\circledR}\right)$ in the shells powder. These compounds were added to the cement pastes and mortar. The cement paste is made with cement and water, while the mortar is the paste with the addition of sand. In addition, cement pastes and mortars of the study were performed with drinking water.

The cement used in this test was the CPII F-40 (Portland with filer, manufacturer Goiás) which has a high potential for the mortars and concretes production. This cement may contain 6 to $10 \%$ carbonates, such as limestone filter which is a chemically inert material.

The sand to determine the properties of the mortar in the hardened state was extracted from the Tietê river and has rounded and sub-leased quartz grains (ABNT, 2015). The granulometric fractions of this sand are in Table 1.

Table 1. Granulometric fractions of the sand

\begin{tabular}{ll}
\hline Fractions & Length of Materials Retained Between Sieves $(\mathrm{mm})$ \\
\hline 16 & 2.4 and 1.2 \\
30 & 1.2 and 0.6 \\
50 & 0.6 and 0.3 \\
100 & 0.3 and 0.15 \\
\hline
\end{tabular}

\subsection{Assay With Fresh Cement Pastes}

The cement pastes were performed in an electric mortar (5.0 L) with five different biopolymer (hydroxyapatite and chitosan) proportions (Table 2). The control was done without the addition of these compounds.

Table 2. Proportions of biopolymer (hydroxyapatite and chitosan) of the crab shells in the cement pastes and mortar

\begin{tabular}{ll}
\hline Treatment & Percentage of biopolymer $(\mathrm{w} / \mathrm{w})$ \\
\hline Control & 0 \\
Paste 1 and mortar 1 & 1 \\
Paste 2 and mortar 2 & 2 \\
Paste 3 and mortar 3 & 3 \\
Paste 4 and mortar 4 & 4 \\
Paste 5 and mortar 5 & 5 \\
\hline
\end{tabular}

The biomaterial influence on cement adherence was determined by the normalized consistency in the Vicat appliance with the Tetmaje probe (ABNT, 2017). The setting time was obtained by the water-cement ratio that was determined by the probe. This time represents the change from fluid to rigid state. 


\subsection{Assays With Hardened Mortars}

The mortars were also performed with biomaterial proportions ranging from 1 to 5 (Table 2) using a concrete mixer (ABNT, 1996). The amount of materials used in this experiment in Table 3 and the water-cement ratio was of 0.48 .

Table 3. Materials used for the production of hardened mortar

\begin{tabular}{ll}
\hline Material & Amount $(\mathrm{g})$ \\
\hline Portland cement & 624 \\
Water & 300 \\
\hline Sand & 468 \\
Coarse fraction & 468 \\
Thick average fraction & 468 \\
Fine medium fraction & 468 \\
Fine fraction & \\
\hline
\end{tabular}

For each time of test and break, six specimens were cast. The samples were molded immediately after kneading with a spatula and a metal socket. We made four layers containing 30 uniform strokes in each. These materials were kept in a humid chamber for 24 hours with the upper face protected by a flat glass plate. After, a part of them was demolded. The other part was kept in a plastic basin with lime-saturated water until the time of each trial.

\subsection{Strength to the Tensile and Water Absorption Content}

The strength to the axial compressive and strength to the tensile by diametrical compression were performed according to NBR 7215 and NBR 7222 standards (ABNT, 1996, 2011; Viana et al., 2009; Giordani \& Masuero, 2019) in automated press (EMIC PCE 150 tf). Prior to each assay, samples were capped using a grinder. For each addition level of biopolymers in the cement, six samples were broken at 28 days of age.

The water absorption content was performed according to NBR 9778 standard (ABNT, 2005) in cement pastes and mortar.

\subsection{Scanning Electron Microscopy With Energy Dispersive Spectroscopy}

The characterization of mortars (dispersion, morphology and particle distribution of biopolymers in the cement matrix and voids in the formed structures) was evaluated by Scanning Electron Microscopy (SEM). Qualitative and semi-quantitative analyzes and spatial distributions of the chemical elements of the samples were obtained by Dispersive Energy Spectroscopy (EDS, Oxford Instruments X-MaxN) with an X-ray detector attached to the microscope (Famy et al., 2003, Singh \& Garg, 2006). The samples used in the SEM/EDS were obtained after the strength to the axial compressive text. These samples were dispersed on copper tape and covered with carbon. The micrographs were obtained under a SEM (Jeol JSM-IT300), vacuum and with electron acceleration voltage of $15 \mathrm{kV}$. These tests were performed in the Laboratory of the Regional Center for Technological Development and Innovation, Federal University of Goiás, Brazil.

\subsection{Statistical Analysis}

The experiment was carried out using six replicates per treatment (control, cement pastes 1 to 5 and, mortar 1 to 5). The data of the tables and figures are the average and plus or minus a standard deviation. These data were also submitted to an analysis of variance and Tukey's test at $5 \%$ of probability.

\section{Results and Discussions}

\subsection{Assay With Fresh Cement Pastes}

The consistency of the materials was higher in the pastes with biopolymer than in the control (Table 4). This result shows that to maintain the consistency of the pastes a greatest amount of water must be added. However, this amount of water was not directly proportional to the amount of biopolymers in the pastes (Table 4). Some pastes had no difference in consistency that may be due to the penetration limit of the Tetmajer probe $(6 \pm 1 \mathrm{~mm})$ into the base plate.

The results of paste consistency (Table 3) were similar to the values obtained Lasheras-Zubiate et al. (2012). According to the authors, chitosan-added mortars have greater water retention than mortar without this 
compound. The hydrophilic groups of chitosan form hydrogen bonds with water and reduce free water by expanding their chains in the solution. Furthermore, the strong flocculant effect of the chitosan shows that there was an adsorption of the additives to cement particles that have positive charges.

Table 4. Consistency of the cement paste with or without of biopolymers (hydroxyapatite and chitosan)

\begin{tabular}{llll}
\hline Cement pastes & Biopolymer $(\mathrm{g})$ & Water $(\mathrm{g})^{*}$ & Probe penetation $(\mathrm{mm})$ \\
\hline Control & 0 & 160 & 6.0 \\
Paste 1 & 5 & 165 & 6.0 \\
Paste 2 & 10 & 170 & 5.0 \\
Paste 3 & 15 & 170 & 6.0 \\
Paste 4 & 20 & 180 & 5.5 \\
Paste 5 & 25 & 180 & 6.5 \\
\hline
\end{tabular}

Note. * Water amount for standard consistency.

Initial and final setting times of cement were higher in pastes with biopolymers than in the control (Table 5). The initial setting time is the time required to start solidifying the paste, while the final setting time is obtained after complete solidification of the paste.

The pastes with biopolymer had initial setting time above 60 min and final setting time less than 600 min (Table 5). These timeouts were determined by ABNT (2017). In addition, cement pastes with 1 and $2 \%$ of biopolymers had the same setting times. However, in the other cement pastes the setting times increased with the addition of biopolymers. This influence of biopolymers on setting times may be a desirable feature due to increased slurry handling time in environments with low relative humidity and high temperatures as in tropical regions.

Table 5. Setting times of the cement pastes with or without of biopolymers (hydroxyapatite and chitosan)

\begin{tabular}{lll}
\hline \multirow{2}{*}{ Cement pastes } & \multicolumn{2}{c}{ Setting time (min) } \\
\cline { 2 - 3 } & Initial & Final \\
\hline Control & 175 & 225 \\
Paste 1 & 190 & 240 \\
Paste 2 & 190 & 240 \\
Paste 3 & 200 & 300 \\
Paste 4 & 225 & 320 \\
Paste 5 & 240 & 330 \\
\hline
\end{tabular}

We observed that biopolymers cause a delay in the cement hydration process (Table 5). According to Nóbrega (2009), this effect is due to the entrapment of calcium ions in chitosan. This author analyzed by X-ray diffraction the hydrates formation cement pastes with and without chitosan addition. Furthermore, the retardation effect caused by chitosan depends on the cement composition and has been very important in cements with low $\mathrm{C}_{3} \mathrm{~A}$ content.

If compared to the control, the largest variation in initial setting time was observed in the pastes with 1 or $2 \%$ biopolymer (Figure 1). However, the final setting time had greatest variations in pastes with biopolymers contents above $2 \%$. 


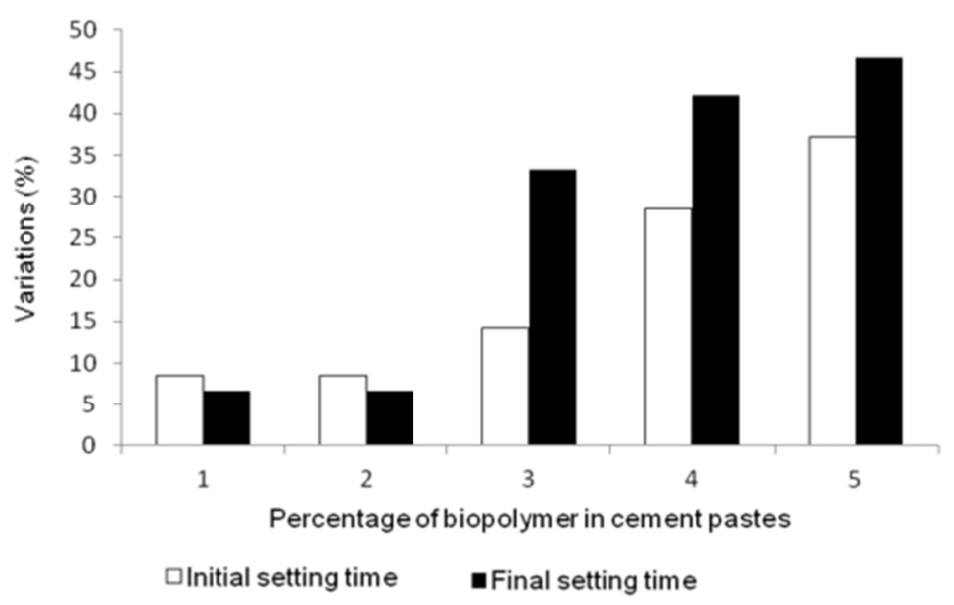

Figure 1. Variations of setting times of cement pastes with biopolymers (hydroxyapatite and chitosan) in relation to the control (Tables 1 and 5)

\subsection{Assays With Hardened Mortars}

In the first 24 hours, the strength to the axial compressive of mortars with the biopolymers was lower than the control (Figure 2). This reduction was greatest in mortar with biopolymer content greater than $2 \%$. The increase of the biopolymers addition in the cement also reduced the setting time of cement pastes (Table 5). These results show that the biopolymers cause a delay in the cement hydration process. Liu et al. (2015) also observed that cement pastes with chitosan have lower strength to the axial compressive than control, in the time of rupture equal to the 24 hours. Thus, the chitosan interferes with cement hydration.

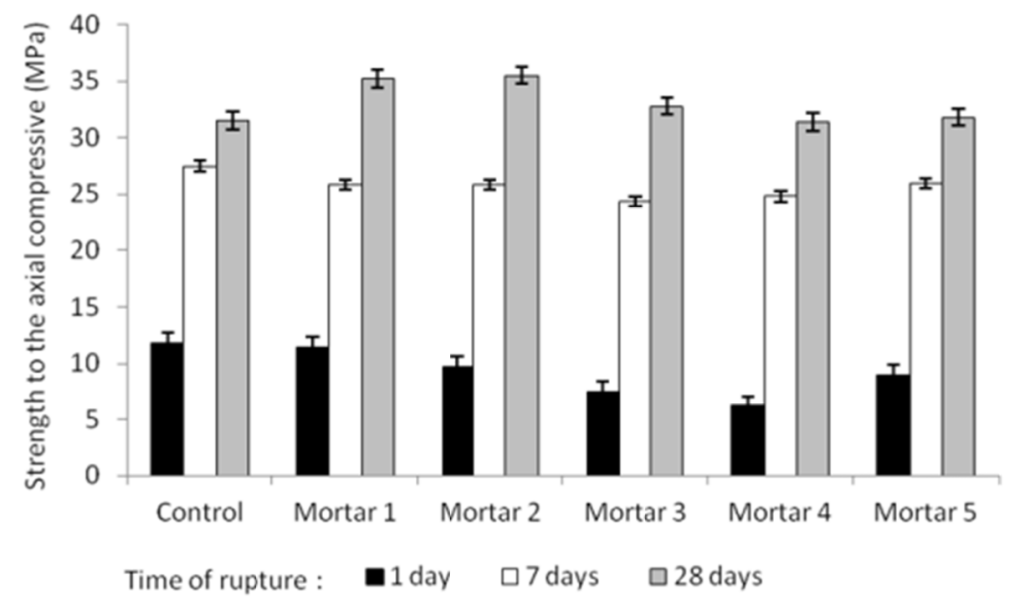

Figure 2. Strength to the axial compressive of mortar with or without of biopolymers (hydroxyapatite and chitosan)

At the time of rupture of 7 days, the mortars had strength to the axial compressive similar to control (Figure 2). During this period, biopolymer additions did not interfere with cement hydration. In the last rupture time, mortars with percentages of biopolymers below $3 \%$ had an increase in strength (Figure 2). The percentage of this increase in strength was 14 (mortar 1), 13 (mortar 2) and 4 (mortar 3) and may be due to chemical interaction between chitosan amino groups and free ion calcium. This ion is obtained from the reaction between $\mathrm{C} 3 \mathrm{~S}$ and plaster. According to Nobrega (2009), chitosan interacts with anhydrous cement grains and occupies voids in the microstructure of hardened cement paste. This biopolymer decreases the permeability of the hardened paste and the fluids percolation. Furthermore, the hydrophilic groups of chitosan also contributed to increased strength to the axial compressive of mortars. According to Lasheras-Zubiate et al. (2012), these groups retain a large amount of water that over time can increase the nucleation points of the cement grains and form a dense and homogeneous paste. 
The tensile strengths by diametrical compression of mortars with 1 and $2 \%$ biopolymers were similar to the control value (Figure 3). In other mortars, we observed a reduction in the value of this resistance.

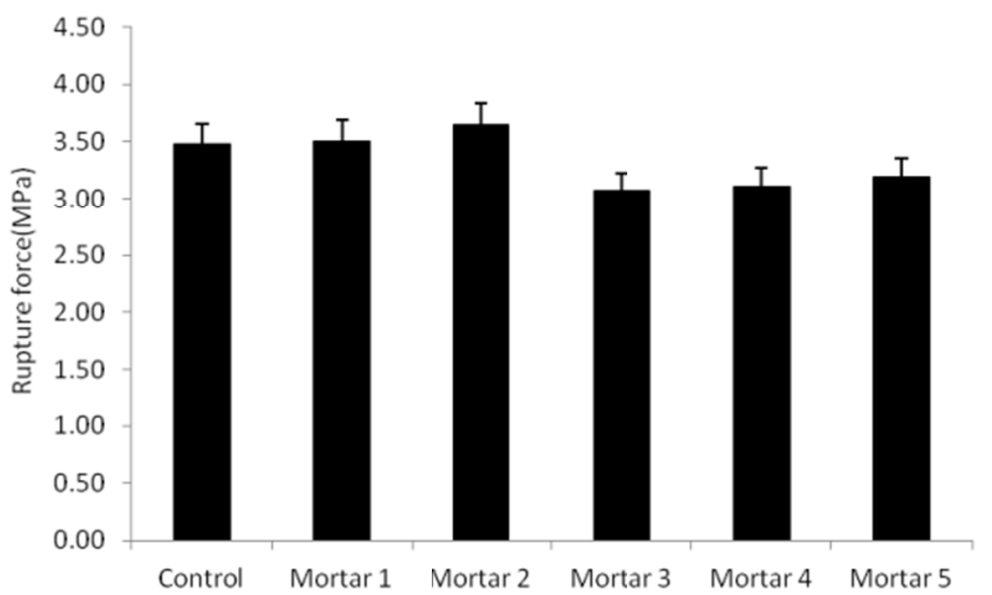

Figure 3. Tensile strengths by diametrical compression of mortar (in 28 days) with or without of biopolymers (hydroxyapatite and chitosan)

The biopolymers cause an increase in water absorption and porosity of mortars which show a low contribution of crab shell biopolymers in mortar durability (Table 6).

Table 6. Mass, water absorption by immersion test and porosity of mortar (in 28 days) with or without of biopolymers (hydroxyapatite and chitosan)

\begin{tabular}{|c|c|c|c|c|}
\hline Mortar & Dry mass & Saturated mass & Water absorption & Total porosity \\
\hline & \multicolumn{2}{|c|}{ 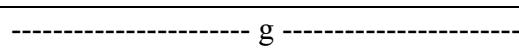 } & \multirow{2}{*}{\multicolumn{2}{|c|}{---------------------- \% ------------------ }} \\
\hline & 406.7 & 441.6 & & \\
\hline \multirow[t]{3}{*}{ Control } & 403.3 & 439.0 & $8.52 \pm 0.26$ & $17.66 \pm 0.43$ \\
\hline & 410.3 & 443.7 & & \\
\hline & 403.3 & 440.4 & & \\
\hline \multirow[t]{3}{*}{ Mortar 1} & 397.5 & 436.0 & $9.49 \pm 0.19$ & $19.37 \pm 0.32$ \\
\hline & 402.4 & 440.9 & & \\
\hline & 401.2 & 438.8 & & \\
\hline \multirow[t]{3}{*}{ Mortar 2} & 395.9 & 432.6 & $9.48 \pm 0.21$ & $19.23 \pm 0.42$ \\
\hline & 394.8 & 433.8 & & \\
\hline & 404.7 & 442.6 & & \\
\hline \multirow[t]{3}{*}{ Mortar 3} & 407.7 & 444.3 & $9.14 \pm 0.15$ & $18.89 \pm 0.2)$ \\
\hline & 405.2 & 442.0 & & \\
\hline & 394.0 & 431.3 & & \\
\hline \multirow[t]{3}{*}{ Mortar 4} & 396.2 & 433.5 & $9.35 \pm 0.14$ & $18.98 \pm 0.02$ \\
\hline & 94.5 & 431.7 & & \\
\hline & 393.8 & 431.5 & & \\
\hline \multirow[t]{2}{*}{ Mortar 5} & 396.7 & 434.2 & $9.56 \pm 0.07$ & $19.20 \pm 0.07$ \\
\hline & 392.6 & 430.5 & & \\
\hline
\end{tabular}

The control mortar had a higher number of microcracks and higher stiffness (aggregate) in the mixture than mortars with biopolymers (Figure 4). These results may be due to lowest strength to the axial compressive of the control (Figure 2). However, mortars with biopolymers had an increase in pores quantity which may be due to the largest water absorption of the mixture (Figure 4, Table 6). 

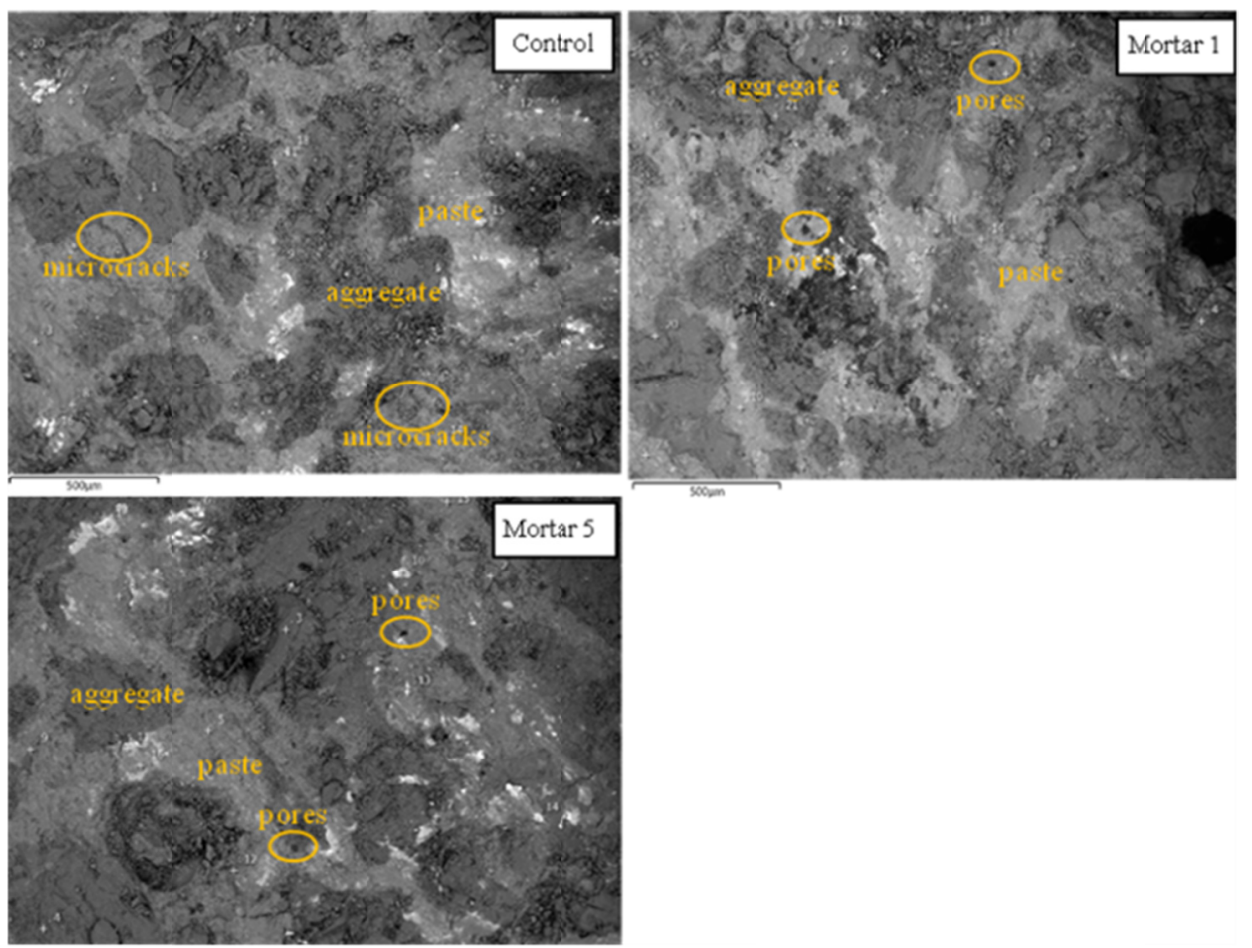

Figure 4. Micrograph of mortars with (mortar 1 and mortar 5) or without (control) of biopolymers after 28 days of production. These micrographs were obtained with a 30 -fold magnification on the Scanning Electron Microscope

In the control mortar a crystal (Figure 5A) with high levels of calcium and silicon (Figure 5B) was observed. The $\mathrm{Ca}$ and Si ratio was 2.1. This value is very common in hydrated calcium silicate.

In mortars with biopolymers, regions (Figure 6A) with high concentrations of calcium and phosphorus (Figures $6 \mathrm{~B}$ and $6 \mathrm{C}$ ) were observed. These results show the calcium phosphate formation of the $U$. Cordatus shells.
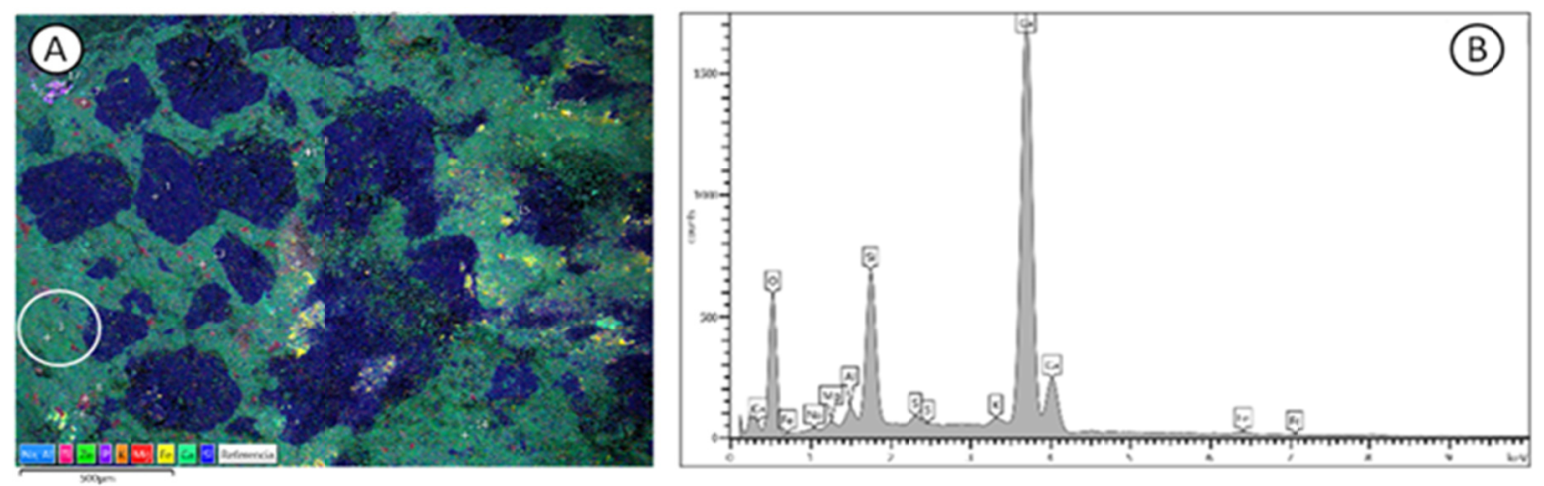

Figure 5. Micrograph (A) and spectrum (B) of the control mortars after 28 days of production. These micrographs were obtained with a 30-fold magnification on the Scanning Electron Microscope. The spectrum was performed in the micrograph region (white circle) by Dispersive Energy Spectroscopy with an X-ray detector 

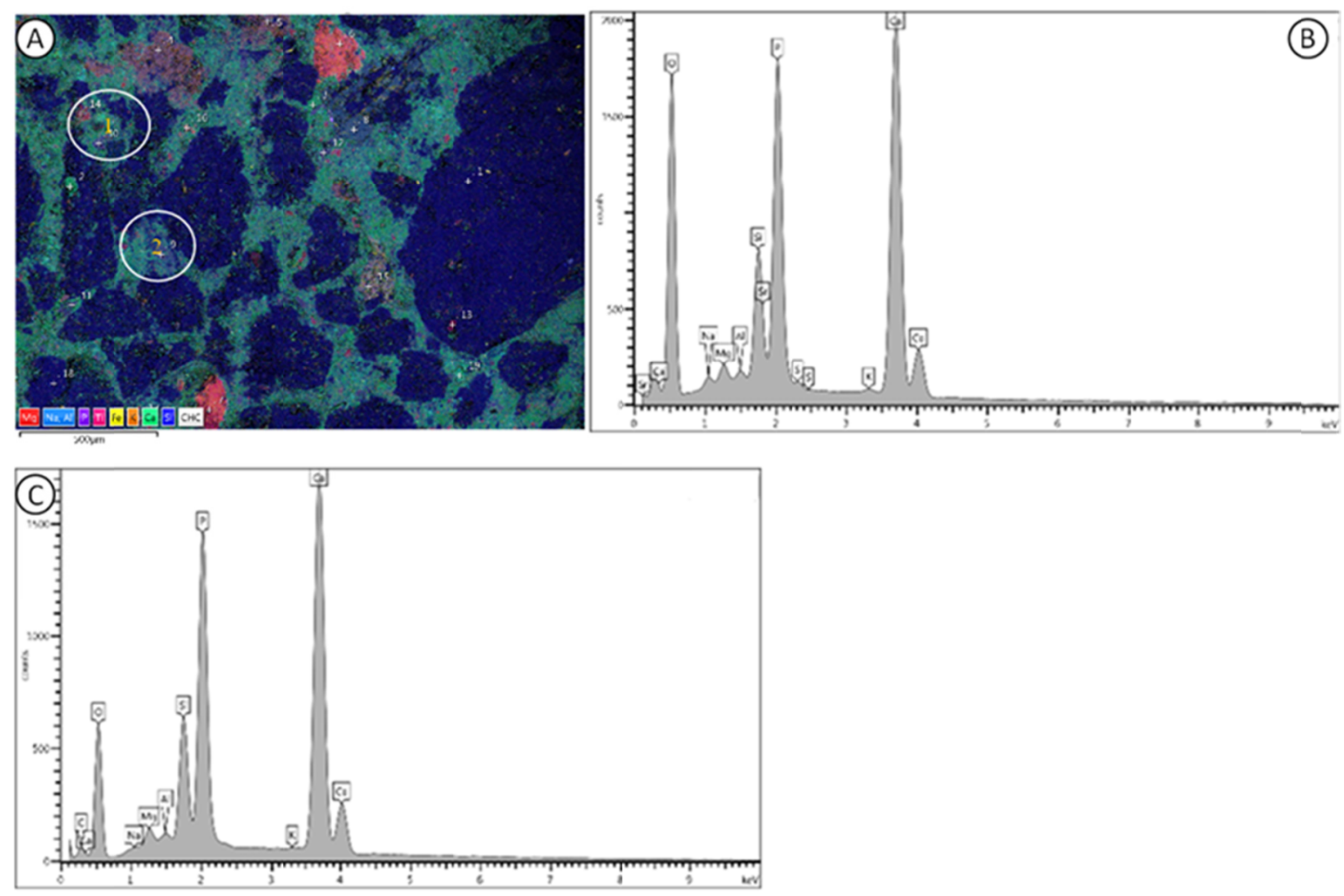

Figure 6. Micrograph (A) and spectra $(\mathrm{B}=$ circle 1 and $\mathrm{C}=$ circle 2$)$ of the mortars with $5 \%$ de biopolimers after 28 days of production. These micrographs were obtained with a 30 -fold magnification on the Scanning Electron

Microscope. The spectra were performed in the micrograph region (white circle) by Dispersive Energy Spectroscopy with an X-ray detector

\section{Conclusions}

In this study, we obtained the following conclusions:

(1) The addition of biopolymers in the cement provided changes in the consistency of pastes that required highest water consumption to maintain control consistency.

(2) The mortars with the biopolymers had a change in water absorption and porosity. However, biopolymers do not compromise mortar durability.

(3) The biopolymers addition in cement promoted a reduction in the mortar microfissures that may influence the stiffness of the mixture.

(4) Phosphorus and calcium concentrations in mortar with 5\% biopolymer show calcium phosphate production.

(5) Our results show the potential of crab shells in biopolymer production to be added to mortars. Furthermore, this process contributes to the reduction of environmental damage caused by improper disposal of crab shells and may represent an economic enhancement of this by-product of the food industry.

\section{References}

ABNT (Brazilian Association of Technical Standards). (2015). Standard sand for cement tests-Specification. (ABNT-NBR 7214:2015). Retrieved from https://www.abntcatalogo.com.br/norma.aspx?ID=348035

ABNT (Brazilian Association of Technical Standards). (2017). Portland cement-Determination of setting times (ABNT-NBR 16607:2017). Retrieved from https://www.abntcatalogo.com.br/norma.aspx?ID=372001

ABNT (Brazilian Association of Technical Standards). (2019). ABNT Portland cement-Determination of compressive strength of cylindrical test specimens (ABNT-NBR 7215:2019). Retrieved from https://www.abntcatalogo.com.br/norma.aspx?ID=348035 
Abreu, F. O. M. S., Cavalcante, L. G., Doudement, P. V., Castro, A. M., Nascimento, A. P., \& Matos, J. E. X. (2013). Development of New Method to Obtain Chitosan from the Exoskeleton of Crabs Using Microwave Radiation. Polímeros Ciência e Tecnologia, 23(5), 630-635. https://doi.org/10.4322/polimeros.2013.042

Benchimol, R. L., Sutton, J. C., \& Dias-Filho, M. B. (2006). Potential of crab shell for reducing incidence of fusariosis and promoting growth of black pepper transplants. Fitopatologia Brasileira, 31(2), 1-5. Retrieved from https://ainfo.cnptia.embrapa.br/digital/bitstream/item/18037/1/30012.pdf

Dorozhkin, S. V. (2016). Calcium orthophosphates $\left(\mathrm{CaPO}_{4}\right)$ : Occurrence and properties. Prog. Biomater., 5, 9-70. https://doi.org/10.1007/s40204-015-0045-z

Famy, C., Brough, A. R., \& Taylor, F. W. (2003). The C-S-H gel of Portland cement mortars: Part I. The interpretation of energy-dispersive X-ray microanalyses from scanning electron microscopy, with some observations on C-S-H, AFm and AFt phase compositions. Cement and concrete Research, 33, 1389-139. https://doi.org/10.1016/S0008-8846(03)00064-4

Giordani, C., \& Masuero, A. B. (2019). Blended mortars: Influence of the constituents and proportioning in the fresh state. Construction and Building Materials, 210, 574-587. https://doi.org/10.1016/j.conbuildmat. 2019.02.077

Lasheras-Zubiate, M., Navarro-Blasco, I., Fernández, J. M., \& Álvarez, J. I. (2012). Effect of the addition of chitosan ethers on the fresh state properties of cement mortars. Cement and Concrete Composites, 34(8), 964-973. https://doi.org/10.1016/j.cemconcomp.2012.04.010

Liu, H., Bu, Y., Sanjayan, J., \& Shen, Z. (2015). Effects of chitosan treatment on strength and thickening properties of oil well cement. Construction and Building Materials, 75, 404-414. https://oi.org/10.1016/ j.conbuildmat.2014.11.047

Nóbrega, A. K. C. (2009). Formulation of cement pastes with addition of chitosan suspensions for oil well cementation. Universidade Federal do Rio Grande do Norte, Brazil. Retrieved from https://repositorio. ufrn.br/jspui/bitstream/123456789/12751/1/FormulacaoPastasciment\%c3\%adcias_Nobrega_2009.pdf

Raya, I., Mayasari, E., Yahya, A., Syahrul, M., \& Latunra, A. I. (2015). Shynthesis and characterizations of calcium hydroxyapatite derived from crabs shells (Portunus pelagicus) and its potency in safeguard against to Dental Demineralizations. International Journal of Biomaterials, Article ID 469176. https://doi.org/ $10.1155 / 2015 / 469176$

Santos, B. S., Santos, T. P. B., \& Farias, G. B. L. (2017a). Identification of the problems associated with the lack of proper management of the residue of the Caranguejo-Uça (Ucides cordatus) culling activity in Bragança, PA, Brazil (pp. 1-6). VIII Congresso Brasileiro de Gestão Ambiental. Retrieved from https://www.ibeas. org.br/congresso/Trabalhos2017/III-060.pdf

Santos, I. M. G. (2017b). Influence of adding biopolymers and hydroxyapatite cement containing pulp of silica for oil well foundation. Universidade Federal de Sergipe, São Cristóvão, SE, Brazil. Retrieved from https://ri.ufs.br/bitstream/riufs/3469/1/ivory_marcos_gomes_santos.pdf

Singh, M., \& Garg, M. (2006). Reactive pozzolana from Indian clays-Their use in cement mortars. Cement and Concrete Research, 36, 1903-1907.

Viana, C. E., Dias, D. P., Holanda, J. N. F., \& Paranhos, R. P. (2009). he use of submerged-arc welding flux slag as raw material for the fabrication of multiple-use mortars and bricks. Soldagem \& Inspecao, 14(3), 14-27. https://doi.org/10.1590/S0104-92242009000300009

\section{Copyrights}

Copyright for this article is retained by the author(s), with first publication rights granted to the journal.

This is an open-access article distributed under the terms and conditions of the Creative Commons Attribution license (http://creativecommons.org/licenses/by/4.0/). 